\title{
The Reading Habits and Preferences of LGBTIQ+ Youth
}

\author{
Rachel Wexelbaum, St. Cloud State University, USA
}

\begin{abstract}
The author of this article presents the available findings on the reading habits and preferences of LGBTIQ+ youth. She will discuss the information seeking behavior of LGBTIQ+ youth and challenges that these youth face in locating LGBTIQ+ reading materials, whether in traditional book format or via social media. Finally, the author will provide recommendations to librarians on how to make LGBTIQ+ library resources more relevant for youth, as well as identify areas that require more research.
\end{abstract}

Keywords: LGBT; LGBT library resources and services; reading; social media; young adults

Publication Type: viewpoint article

esbian, gay, bisexual, transgender, intersex, queer, and questioning $\left(\mathrm{LGBTIQ}+{ }^{1}\right)$ youth today, like the generations of LGBTIQ+ youth before them, are active readers (Wargo, 2017). While LGBTIQ+ youth seek out books about LGBTIQ+ characters and issues, they also rely heavily on social media as a source of reading (Birdi \& Ford, 2018; Brammer, 2017; Craig \& McInroy, 2014; Fox \& Ralston, 2016; McBee, 2013; Pruitt, 2016; Robards, 2016; Wargo, 2017; Wexelbaum, 2015a; Wexelbaum, 2015b; Wexelbaum, 2017b). LGBTIQ+ youth consume a wide variety of content for community building, educational purposes, entertainment, self-reflection, and sanctuary (Birdi \& Ford, 2018; Brammer, 2017; Craig \& Mclnroy, 2014; Fagan, 2013; Flanders, Pragg, Dobinson, \& Logie, 2017; Hamer, 2003; Hillier \& Harrison, 2007; Kivel \& Kleiber, 2000, p. 222-223; Lucero, 2017; McBee, 2013; Paridis, 2016; Pruitt, 2016; Wargo, 2017; Wexelbaum, 2017a; Wexelbaum, 2017b). To this day, librarians serving LGBTIQ+ youth continue to focus predominantly on books and films in their efforts to provide LGBTIQ+ resources and services for youth (Cart \& Jenkins, 2004; Chapman, 2013; Chapman, 2014; Chapman, 2015; Naidoo, 2015; Oltmann, 2015; Wexelbaum, 2017a). In reality, these traditional media may only appeal to a small percentage of LGBTIQ+ youth who may prefer reading blogs on Tumblr or seeking out information in more interactive contexts such as Facebook groups or Twitter communities (McBee, 2013; Robards, 2016; Wargo, 2017).

Depending on the country in which they live, LGBTIQ+ youth experience very different levels of protection and information access at home, school, and in libraries (Equaldex, 2018; Gay Lesbian Straight Education Network, 2018; International Lesbian and Gay Association, 2017; Stewart, 2009; UNESCO, 2012a; UNESCO, 2012b; Wexelbaum, 2015a; Wexelbaum, 2017b). The Gay Lesbian Straight Education Network (GLSEN) and UNESCO developed international best practices to improve LGBTIQ+ support and representation in school environments, curriculum, and textbooks and to eliminate LGBTIQ+ related school bullying (UNESCO, 2012a; UNESCO, 2012b). For some reason, neither of the UNESCO reports address libraries as a source of support for LGBTIQ+ youth. Libraries play a special role in providing sanctuary and information resources for LGBTIQ+ youth, however, and for this reason the information provided in this article should be of interest to 
librarians, educators, and all practitioners dedicated to improving the welfare of youth around the world.

The International Federation of Library Associations and Institutions (IFLA) states that all librarians and information workers still must provide equitable information access and service to all people regardless of their status in the country where they work. According to the IFLA Code of Ethics for Librarians and Other Information Workers "Part 2. Responsibilities toward individuals and society":

In order to promote inclusion and eradicate discrimination, librarians and other information workers ensure that the right of accessing information is not denied and that equitable services are provided for everyone whatever their age, citizenship, political belief, physical or mental ability, gender identity, heritage, education, income, immigration and asylum-seeking status, marital status, origin, race, religion or sexual orientation. (IFLA, 2016)

The International Federation of Libraries and Archives (IFLA) acknowledges that, as a global professional organization for information professionals around the world, it must do better to provide professional support for librarians of all nations in regard to meeting the needs of LGBTIQ+ users:

As part of our professional commitment to provide access to information, librarians are charged to support the full range of users' informational needs including those of lesbians, gay, bisexual, transgender, queer/questioning (LGBTQ) people. That said, substantial discussion of issues related to library services for LGBTQ community members have not taken place at IFLA. The LGBTQ Users SIG will address this gap in professional knowledge by offering opportunities to engage in discussions about this often invisible user group. (IFLA, 2015)

As the author writes this article, the IFLA LGBTQ+ Users SIG is developing an international, multilingual survey to determine how libraries around the world currently provide resources, services, space, and programming for LGBTIQ+ populations. The group will use the results of that survey to draft international guidelines for LGBTIQ+ resources, services, library space, and programming. To support IFLA's work, and to improve LGBTIQ+ collection development practices, the author of this article presents the available findings on the reading habits and preferences of LGBTIQ+ youth through a review of existing scholarly, professional, and popular resources. She will discuss the information seeking behavior of LGBTIQ+ youth and challenges that these youth face in locating LGBTIQ+ reading materials, whether in traditional book format or via social media. Finally, the author will provide recommendations to librarians on how to make LGBTIQ+ library resources more relevant for youth, as well as identify areas that require more research.

\section{A New Definition of Reading}

A broadly accepted definition of "reading" is "discover(ing)" information "by reading it in a written or printed source" (Oxford Living Dictionaries, 2018). At the same time, this definition may no longer serve 21st-century readers of younger generations. To this day, English teachers, reading specialists, and librarians differ in their definitions of reading, and continue to focus on the book as the main currency of literacy (Brown, 2017; Commission on Reading of the National Council of Teachers of English, 2004; International Reading Association, 2014; Moyer, 2010; 
National Endowment for the Arts, 2007; National Endowment for the Arts, 2009; National Literacy Trust, 2017). For this reason, national studies of youth reading habits give the impression that youth read less than in previous generations (National Endowment for the Arts, 2007; National Endowment for the Arts, 2009; National Literacy Trust, 2017). While the print book continues to serve as a mode of information gathering and entertainment for youth (National Endowment for the Arts, 2009; National Literacy Trust, 2016; Zickuhr \& Rainie, 2014), they spend more time consuming online social media that combines text, images, and audiovisual content (National Literacy Trust, 2016; Zickuhr \& Rainie, 2014). The failure to include social media within the scope of a definition of reading paints a false picture of the amount of reading that youth actually do and of their desire to read.

Surveys of youth in English-speaking countries reveal conflicting information about the amount of reading that youth actually do (International Reading Association, 2014; Moyer 2010; National Endowment for the Arts, 2007; National Endowment for the Arts, 2009; Rainie, 2018; Zickuhr \& Rainie, 2014). Studies conducted by English teacher associations and reading associations state that the amount of reading that youth do decreases as they grow older, and that youth develop a disdain for reading books because they are required to read materials that do not interest them (International Reading Association, 2014; National Endowment for the Arts, 2007; National Endowment for the Arts, 2009). At the same time, the Pew Internet Survey and library associations state that youth are the highest percentage of library users and that they check out more books than older populations (Moyer 2010; Rainie, 2018; Zickuhr \& Rainie, 2014). Finally, publishing associations note that the sale of books is actually increasing in this age of social media, with books for children and young adults making up a significant percentage of those sales (Cain, 2016; Peterson, 2018).

LGBTIQ+ youth read a wide variety of physical and electronic material formats. These materials include print books, electronic books, blogs, and social media content. For these youth, reading often takes the form of a social activity, an identity-affirming activity, and an emotional regulation activity much more so than an academic cognitive process (Bittner, 2017; Blackburn \& Clark, 2011; Brammer, 2017; Craig \& Mclnroy, 2014; Fabian, 2015; Fagan, 2013; Flanders et al., 2017; Hamer, 2003; Hillier \& Harrison, 2007, p. 95; Kivel \& Kleiber, 2000, p. 222-223; Lucero, 2017; Paridis, 2016; Pruitt, 2016; Wexelbaum, 2017a; Wexelbaum, 2017b). For these reasons, for future assessments of reading habits and preferences of LGBTIQ+ youth, we must develop a new definition of reading.

\section{Limitations of Current Research on LGBTIQ+ Reading Habits and Preferences}

Studies conducted on the traditional reading habits of youth do not collect information on the sexual orientation or gender identity of participants. Compounding this problem, the research articles written for and by librarians on traditional LGBTIQ+ collection development for youth often do not include qualitative or quantitative evidence of the reading preferences of their young LGBTIQ+ patrons. Instead, these papers focus on what librarians ought to do based on the experiences of older generations of LGBTIQ+ librarians whose reading preference, historically, has been print books (Cart \& Jenkins, 2004; Chapman, 2013; Chapman, 2014; Chapman, 2015; Naidoo, 2014, p. 86; Naidoo, 2015; Oltmann, 2015; Wexelbaum, 2017a). Reviewers of LGBTIQ+ books for youth and panelists on book award panels are often at least one generation removed from the readers whom the librarians aim to serve.

The few studies that do exist of reading habits and preferences of LGBTIQ+ populations often include readers from all age groups (Abrams, 2013; Creelman, 1990; Freely, 2013; Goldthorp, 
2007; Joyce \& Schrader, 1997; Norman, 1999; Pruitt, 2016; Rothbauer, 2004; Wexelbaum, 2015b). These studies originate from English-speaking countries where most study participants identify as white and have access to libraries that have LGBTIQ+ collections and unfiltered, ubiquitous broadband Internet (Goldthorp, 2007; Pruitt, 2016; Rothbauer, 2004a; Rothbauer, 2004b; Rothbauer, 2004c; Wexelbaum, 2015a; Wexelbaum, 2015b; Wexelbaum, 2017). Most studies of LGBTIQ+ youth reading habits focus on small populations who may not accurately represent "the average" LGBTIQ+ youth (Bittner, 2017; Goldthorp, 2007; Kievel \& Kleiber, 2000; Pruitt, 2016; Rothbauer, 2004a; Rothbauer, 2004b; Rothbauer, 2004c). Finally, not all researchers who collect data on reading habits include social media consumption within their definition of reading. For these reasons, we can only speak about the reading habits of a privileged few, and can only estimate the reading habits and preferences of a global LGBTIQ+ youth. More research is needed on the reading habits and preferences of non-English speaking LGBTIQ+ youth, as well as those LGBTIQ+ youth living in non-English speaking countries.

\section{Desire and Motivation to Read Among LGBTIQ+ Youth}

Studies of LGBTIQ+ youth reveal that LGBTIQ+ identity development processes are their primary motivators to read. Through reading, they seek out others like themselves, role models, and safe spaces to live as they wish (Craig \& McInroy, 2014; Hamer, 2003; Kivel \& Kleiber, 2000, p. 222-223). For younger LGBTIQ+ people, the motivation to read begins as an escape from hostility (Fagan, 2013). Some studies find that a significant percentage of LGBTIQ+ youth also receive labels such as "gifted," "talented," and "overperforming" (Cowan, 1988; Hegarty, 2011; Hoskinson, 2001; Pachankis \& Hatzenbuehler, 2013; Stern, 2013; Treat, 2006; Wexelbaum \& Hoover, 2014, p. 74-75; Wilcove, 1998), these students are often placed into or select accelerated classes where they are expected to read more books, therefore socializing with a peer group who read. In a study of 10,000 LGBTIQ+ teenagers, $94.5 \%$ stated that they intended to go to college and had no concerns about academics (Human Rights Campaign, n.d; Kosciw \& Boesen, 2015). Of those college bound survey participants, $69.7 \%$ stated that they would major in an arts, humanities, or social sciences discipline when they went to college (Kosciw \& Boesen, 2015). These subject areas require a great deal of reading and interpretation of texts.

LGBTIQ+ youth engage in heavy social media usage (Brammer, 2017; Craig \& Miclnroy, 2014; Flanders et al., 2017; Hillier \& Harrison, 2007; Lucero, 2017). Their motivation to go online is to search for others like themselves, to be out, and to locate LGBTIQ+-specific information about sexuality and health (Brammer, 2017; Craig \& McInroy, 2014; Flanders et al., 2017; Hamer, 2003; Hillier \& Harrison, 2007, p. 95; Lucero, 2017; Paridis, 2016). LGBTIQ+ youth are often active social media users due to heteronormative physical spaces such as school, home, or libraries restricting their access to traditional information resources (Craig \& Mclnroy, 2014, p.98; Flanders et al., , 2017; Paridis, 2016; Wexelbaum, 2017). They are five times more likely than cisgender heterosexual youth to search online for sexuality and health information (Gay Lesbian Straight Education Network, 2013). While LGBTIQ+ youth enjoy Twitter, Facebook, Instagram, and Snapchat as much as their cisgender heterosexual peers, they are more frequent users of Tumblr, YouTube, and LGBTQ+ blogs (Brammer, 2017; Fabian, 2015; Pruitt, 2016). In fact, a Google search for "Igbt blogs" yields several authoritative lists of recommended LGBTIQ+ blogs, including a "Top 60 LGBT Blogs and Websites for the LGBT Community" blog, updated regularly (Agarwal, 2018). These blogs encourage LGBTIQ+ youth to follow the bloggers, share content on other social media platforms, and discuss the content with others. In some cases, the LGBTIQ+ youth who read blogs about LGBTIQ+ issues find their voice, gain consciousness, and decide to

The International Journal of Information, Diversity, \& Inclusion, 3(1), 2019

ISSN 2574-3430, https://jps.library.utoronto.ca/index.php/ijidi 
generate their own content for others to read, share, and discuss (Brammer, 2017; Fabian, 2015; Pruitt, 2016).

\section{How LGBTIQ+ Youth Locate Reading Material}

The ways in which LGBTIQ+ youth locate reading material differ from context to context. In some instances, locating desired LGBTIQ+ reading material is serendipitous, while in other cases, youth may employ intentional strategies with the help of people, search engines, and social media algorithms (Bittner, 2017; Schaller, 2011). Different populations within the LGBTIQ+ community may have distinct preferences for locating LGBTIQ+ reading material based on availability of options, access to libraries or resource centers with quality reading material and friendly staff, and personal Internet access (Bittner, 2017; Hamer, 2003).

\section{Family and Friends}

Today, more youth are growing up with LGBTIQ+ parents, family members, and friends. These youth may serendipitously encounter LGBTIQ+ books and films at home or in the homes of their family members or friends. Children with same-sex parents or transgender parents may receive picture books about children in similar families, which reflects their family structure and validates their identities. If these youth come out to their parents, family members, or friends who own LGBTIQ+ reading materials, it is possible that those trusted allies would recommend or share LGBTIQ+ books and media with the youth.

\section{Teachers}

More schools are incorporating LGBTIQ+ content into curriculum to meet state or national standards (California Department of Education, 2018; Illinois General Assembly, 2018; RFSU, 2017). Students going to those schools may encounter LGBTIQ+ historical figures, artists, writers, musicians, theorists, or scientists in their school textbooks. It is possible that students may have to complete a research assignment involving a notable LGBTIQ+ person from their class reading. This would require that students visit the library, if they have access to one, or go online to locate information.

\section{Librarians}

Youth unaccustomed to using their library on a regular basis may experience "library anxiety" where they become overwhelmed by the vast number of books and complexity of the library website and catalog (e.g., Cleveland, 2004). LGBTIQ+ youth experience additional stress in library environments if they perceive that library employees or patrons will harm them if they request or search for LGBTIQ+ materials (Drake \& Bielefield, 2017; Oltmann, 2016; Wexelbaum, 2015a; Wexelbaum, 2015b; Wexelbaum, 2017b). To this day, youth may feel uncomfortable asking library employees for assistance in locating or checking out materials, or will assume that they do not have any (Drake \& Bielefield, 2017; Naidoo, 2014; Rothbauer, 2004b). For that reason, they may leave the library without attempting to search, or will search the Internet for materials that may not be part of the library collection (Drake \& Bielefield, 2017; Rothbauer, 2004b; Rothbauer, 2004c). According to library literature, some LGBTIQ+ youth want a standalone LGBTIQ+ collection to make LGBTIQ+ books easy to find, although such a section would make other LGBTIQ+ youth feel "ghettoized" and at risk for harm (Chapman, 2013). Libraries that have LGBTIQ+ ebooks, online subject guides, lists of recommended LGBTIQ+ books on the library website, or LGBTIQ+ books integrated in regular displays make it easier and safer for 
youth to locate those materials (Naidoo, 2014; Wexelbaum, 2015a; Wexelbaum, 2015b; Wexelbaum, 2017b). Public library events such as "Drag Queen Story Hour" and LGBTIQ+ children's literature for a broad audience have begun to normalize queer bodies in the library (https://www.dragqueenstoryhour.org/).

\section{LGBTIQ+ Community Center or Resource Center}

If youth live in proximity of an LGBTIQ+ community center or LGBTIQ+ resource center, they may have access to a computer lab and a book collection (CenterLink, 2018, p. 3; Marine, 2011; Sanlo, 2000). ${ }^{2}$ The LGBTIQ+ center may be less likely to have someone on staff to manage the book collection, but those interested in reading have a safe space to browse and read books that may be unsafe to read in other spaces. Otherwise, the youth could make use of the computer lab to search for LGBTIQ+ content (CenterLink, 2018). Forty-four percent of LGBTIQ+ community centers provide services for homeless LGBTIQ+ youth (CenterLink, 2018, p. 18); it is likely that LGBTIQ+ youth who visit these community centers also use computers there.

\section{Social Media and the Internet}

LGBTIQ+ youth perceive the Internet as a "safe space" (Hillier, Mitchell, \& Ybarra, 2012; Schaller, 2011; Wexelbaum, 2017b). Reading often is a social activity for LGBTIQ+ youth (Birdi \& Ford, 2018; Brammer, 2017; Fagan, 2013; Hillier \& Harrison, 2007; Pruitt, 2016; Wexelbaum, 2017b). Through online communities and private groups on mediated social media channels, LGBTIQ+ youth have found not only community, but fellow readers and spaces to talk about and recommend reading materials-some published by others, and some created by themselves.

Some youth like to go online to check reviews of a book prior to reading it (Bittner, 2017; Pruitt, 2016). This desire to check reviews, combined with the sociability of reading, may indicate why the LGBTIQ+ reading community has an active presence on GoodReads. As of October 2018, 591 LGBTIQ+-specific active book groups exist on GoodReads. Of those LGBTIQ+-specific book groups, the "YA [Young Adult] LGBT Books" group has almost 11,000 members-the second largest LGBTIQ+ book group on GoodReads. Facebook, Twitter, and Tumblr also have groups dedicated to LGBTIQ+ youth who enjoy reading and talking about books. Pruitt (2016) describes a YouTube channel called "BookTube" where he studied the queer space created by seven different LGBTIQ+ readers to discuss and critique LGBTIQ+ books and authors as well as cisgender heterosexual authors.

\section{Bookstores}

As of 2018, fifty queer bookstores still exist in North America, Europe, Asia, Australia and New Zealand (Oder, 2018). Unfortunately, the majority of LGBTIQ+ youth have no access to these stores. If they do purchase LGBTIQ+ books, they will most likely choose Amazon as their "bookstore" (Wexelbaum, 2015b, p. 216-218). While the Amazon site is easier to use than a library catalog, people searching for LGBTIQ+ ebooks through Amazon may perceive that the ebooks are of poorer quality than traditionally published LGBTIQ+ books if they do not know what search terms to use or do not have an exact title or author in mind (Wexelbaum, 2015b, p. 216218). While more mainstream bookstores are increasing their LGBTIQ+ inventory and inviting LGBTIQ+ authors for readings and signings, or making space for LGBTIQ+ book discussion groups, they still do not actively promote LGBTIQ+ books or events for children or young adults. 


\section{Reading Preferences of LGBTIQ+ Youth}

In 2016, researchers asked survey participants to write in the term that best described their gender and sexual orientation and received over 500 distinct responses (Steinmetz, 2017). LGBTIQ+ youth today, diverse and hyperindividualistic, is nearly impossible to pin down for publishers as a marketing demographic. For this reason, there is no current information from publishers about the book purchasing habits of LGBTIQ+ youth.

From online sites such as GoodReads where people have the opportunity to review books, researchers will not always know whether or not a review came from an LGBTIQ+ youngster unless they self-identify. GoodReads does allow people to create lists of books with a common theme or genre, where other GoodReads users can vote, but the number of voters is often small compared to the number of people in the LGBTIQ+ GoodReads community as a whole. Neither Amazon nor libraries collect information on the sexual orientation, gender, or age of their users. For this reason, most information on the reading preferences of LGBTIQ+ youth is historical and anecdotal.

Since the advent of paperback novels, science fiction and fantasy have been popular genres for LGBTIQ+ youth (Bittner, 2017; Foster, 2017; Smith, 2016). This is because science fiction and fantasy stories have opened up realms of possibilities for alternative modes of reproduction and non-cisgender heteronormative societies (Marchesani, 2002). LGBTIQ+ youth who identify as science fiction and fantasy fans go beyond traditionally published books in this genre and will visit fan fiction and slash fiction sites, ${ }^{3}$ where peers will write and share their own stories-often with a queer twist-based on existing science fiction and fantasy stories (Berger, 2010; Bittner, 2017).

According to one recent large scale online survey of self-identified LGBTIQ+ youth (13 to 21 years old) who use the Internet, 31\% of LGBTIQ+ youth go online "mostly to gain information about LGBTQ lives, people, culture, or history" (Paridis, 2016, p. 95). This response was the second most popular reason to go online, after "socialize." While none of the survey questions asked where exactly they go online to search for such information, or what type of resources they prefer, it is highly likely that the youth would retrieve Wikipedia articles, blog posts, online journal articles, and access to ebooks on these topics. Historically, LGBTIQ+ youth have searched for books that had LGBTIQ+ characters like themselves (Blackburn \& Clark, 2011). As students are coming out and claiming their gender identities at earlier ages, underrepresentation of LGBTIQ+ characters in composition readers and textbooks force these students into silence and invisibility in the classroom, prodding them to search for such characters in their leisure reading (Hudson, 2007).

Major concerns of LGBTIQ+ youth include finding LGBTIQ+ friends and romantic partners. More LGBTIQ+ youth search for friends and romantic partners online than non-LGBTIQ+ youth (DeHaan, Kuper, Magee, Bigelow \& Mustanski, 2012; Hillier, Mitchell, \& Ybarra, 2012). This also generates interest in stories about LGBTIQ+ friendships and romance and could explain why publishers and librarians promote young adult literature with such themes to teenagers, and why some LGBTIQ+ young adult novels, such as Nancy Garden's Annie on My Mind (1982), still resonate with young readers today (Stepaniuk, 2018).

Australian researchers who conducted a large-scale study of the social media use of LGBTIQ+ youth discovered that over $60 \%$ of LGBTIQ+ youth in Australia use Tumblr (Robards, 2016). These youth considered Tumblr the most useful of all social media sites because of the safe "queer

The International Journal of Information, Diversity, \& Inclusion, 3(1), 2019

ISSN 2574-3430, https://jps.library.utoronto.ca/index.php/ijidi 
ecosystem" in that space, the community building, and the information that they received from peers about gender, sexuality, and activism (Robards, 2016). American and British youth have echoed these sentiments about Tumblr, particularly those who identify as transgender (McBee, 2013; Wargo, 2017).

\section{Challenges for Young LGBTIQ+ Readers}

LGBTIQ+ youth in rural, socially conservative areas often have the least access to LGBTIQ+ content (Bittner, 2017; Naidoo, 2014; Wexelbaum, 2017b). If their school or public library does not have LGBTIQ+ books, and if their school and family maintain Internet filters on the computers, they will struggle to locate LGBTIQ+ reading material or find an LGBTIQ+ community (Bittner, 2017; Wexelbaum, 2015a; Wexelbaum, 2017b).

More K-12 school districts are doing away with school librarians-and sometimes librariesaltogether, and few K-12 teachers are teaching students about online searching or how to evaluate online information (Kachel, 2018). For these reasons, LGBTIQ+ youth may have a more difficult time searching independently for traditional reading materials if they do not have friends or trusted adults who can help. They may also struggle in locating authoritative, trustworthy information about safe sex, transitioning, or other LGBTIQ+ specific issues. While blogs written by peers can be entertaining or affirming, they are no substitute for professional medical guidance or advice from a mental health professional.

A small study of 35 Canadian transgender and queer youth from British Columbia who identify as active readers and library users revealed that this population found most LGBTIQ+ fiction didactic, alienating, and portraying stereotypes (Bittner, 2017, pp. 109-110). While researchers should replicate this study with transgender and queer youth across North America to confirm whether this perception is common within this population, it is true that the number of YA novels with transgender or queer characters remains small, and that they are often written for the purpose of educating or entertaining cisgender people (Bittner, 2017, p. 74-75).

LGBTIQ+ youth with multiple identities-LGBTIQ+ youth of color and LGBTIQ+ youth with disabilities in particular-remain underrepresented in traditional reading materials. As the majority of LGBTIQ+ online spaces remain predominantly white and able-bodied, these youth do not always feel safe or fully accepted in these environments. Unless they have friends or trusted adults who can help them locate the resources they need to locate community and seek validation, these youth may be at higher risk for self-harm (Haas, Rodgers, \& Herman, 2014).

LGBTIQ+ youth-particularly LGBTIQ+ youth of color-are over $120 \%$ more likely to experience homelessness than white cisgender heterosexual youth (Dashow, 2017). An estimated 20 to 40 percent of LGBTIQ+ youth in the U.S. experience homelessness, disrupting their education and free time to reflect (Lambda Legal, n.d.; True Colors Fund, 2018). Homeless LGBTIQ+ youth depend heavily on libraries and LGBTIQ+ community centers for temporary shelter, access to services, information, and computers (CenterLink, 2018; Lambda Legal, n.d). While no information exists on the leisure reading habits of homeless LGBTIQ+ youth, all homeless youth seek out print and online guides providing contact information for shelters, counseling services, food banks, HIV testing, pregnancy testing, and other sexual health or medical services in safe, welcoming spaces (Hill, 2016; Lambda Legal, n.d.; Winkelstein, 2013). Some LGBTIQ+ homeless youth also try to connect with online educational opportunities in libraries, including test preparation services (Hill, 2016; Lambda Legal, n.d.; Winkelstein, 2013). The American Library Association's Gay Lesbian Bisexual Transgender Roundtable recognizes the needs of LGBTIQ+ 
homeless youth and published an excellent resource guide produced by Julie Ann Winkelstein for the 2013 American Library Association Annual Conference called "Safe in the Stacks: Community Spaces for Homeless LGBT Youth" (Winkelstein, 2013).

Minors, homeless and otherwise, do not have the same level of physical privacy as adults, which could affect their ability to bring home library books or other physical media with LGBTIQ+ content (Naidoo, 2014; Wexelbaum, 2015a; Wexelbaum, 2017b). Not all minors have the same level of Internet privacy as adults, especially in school libraries (Naidoo, 2014; Wexelbaum, 2015a; Wexelbaum, 2017b). If minors do have access to unfiltered Internet and go to unmonitored social media sites, they may encounter graphic talk or videos for which they may not be prepared. One study revealed that, for LGBTIQ+ ebooks on Amazon without proper search terms, the odds that they retrieve erotica or pornographic material will be high (Wexelbaum, 2015b).

Finally, while LGBTIQ+ youth view the Internet as "safe," they are at higher risk for bullying, sexual harassment, and online crime than cisgender heterosexual youth (Gay Lesbian Straight Education Network, 2015, pp. x-xii). Negative experiences online may affect their desire to seek out LGBTIQ+ information, reading material, or community online.

\section{Recommendations and Future Research}

Based on current findings, LGBTIQ+ youth have a high motivation to read. They seek out traditional reading materials and online media to locate LGBTIQ+-related information, to validate their identity, to find community, and to share experiences and knowledge. As LGBTIQ+ youth spend more time online than cisgender heterosexual youth (Gay Lesbian Straight Education Network, 2015, pp. x-xii), it is important for teachers and librarians to reach LGBTIQ+ youth through social media channels and other online fora to provide reading recommendations for online resources as well as traditionally published books (e.g., Wexelbaum, 2017).

GoodReads remains an untapped source of data about LGBTIQ+ book readers, as are Tumblr, Twitter, and the moderated Facebook groups for LGBTIQ+ readers. These sites remain highly popular and stable; in English-speaking countries, at least, they show no sign of disappearing. With respect to anonymity and user privacy, discovering strategies to mine that data to learn more about contemporary LGBTIQ+ youth reading preferences would greatly benefit librarians, teachers, publishers, and writers. With that said, young LGBTIQ+ readers are a diverse group; it is quite possible that differences in reading habits and preferences exist within this population that may also provide more information as to the differences in reading habits and preferences between genders, sexualities, races, and other demographics.

As younger generations consume multiple forms of content, the definition of reading should include the interpretation of online multimedia as well as traditional print books. Once that is established, researchers can adjust the questions they ask youth in surveys about their reading habits and preferences. In the case of determining reading habits and preferences for LGBTIQ+ youth, researchers must include their online information seeking behavior and find out what types of sites they visit for that information. In conducting these studies on the online information seeking behavior of LGBTIQ+ youth, researchers should always include specific questions about the use of the library website or catalog to locate information, social media channels, or other online fora, as opposed to the general Internet-related questions. Librarians still do not know if or how LGBTIQ+ youth access their online resources, and without that information, we will continue to make assumptions about this population based on what we did when we were children.

The International Journal of Information, Diversity, \& Inclusion, 3(1), 2019

ISSN 2574-3430, https://jps.library.utoronto.ca/index.php/ijidi 


\section{Endnotes}

\footnotetext{
${ }^{1}$ The author will use the acronym "LGBTIQ+" to capture the broadest spectrum of sexual and gender identities possible. The author uses "transgender" and "queer" in this acronym as umbrella terms to capture all other possible gender and sexual identities. The new generation of LGBTIQ+ youth, incredibly diverse and hyperindividualistic, employs a much broader spectrum of labels to identify themselves than previous generations. No acronym can capture the full range of identity labels used by sexual minority youth and gender non-conforming youth. Organizations cited in this article often use other variations of this acronym; the author will maintain the integrity of those organizational names and titles.

2 The national organization CenterLink: The Community of LGBT Centers publishes a report on facilities, budgets, staffing, and usage demographics for LGBT community centers that does not include information about book collections. The Consortium of LGBT Higher Education LGBT Resource Professionals maintains a website called "Find an LGBT Resource Center," and Campus Pride has a "Pride Index" that tells potential college students about LGBTIQ+ resources, services, and climate at higher education institutions, but none of these resources provides information about the book collections at LGBT community centers or resource centers. The author of this paper, in preparing another publication, reviewed existing LGBT resource center and LGBT community center webpages to determine how many have book collections. More than three quarters of those centers have book collections.

${ }^{3}$ Slash fiction is "a type...of fan fiction involving...same-sex romantic relationships between fictional characters or famous people, whether or not the romances actually exist [in the original narratives or in real life]" (Dictionary.com, 2018).
}

\section{References}

Abrams, D. (2013, February 14). Survey underway on LGBT reading habits and book discovery. Publishing Perspectives. Retrieved from http://publishingperspectives.com/2013/02/survey-underway-on-lgbt-reading-habitsand-book-discovery/

Agarwal, A. (2018, January 21). Top 60 LGBT blogs and websites for the LGBT community. Feedspot. Retrieved from https://blog.feedspot.com/lgbt_blogs/

Berger, R. (2010). Out and about: Slash fic, re-imagined texts, and queer commentaries. In C. Pullen and M. Cooper (Eds.), LGBT identity and online new media (pp. 173-184). New York: Routledge.

Bittner, R. (2017). Theorizing trans readership: Examining ways of reading trans themed young adult literature (Unpublished doctoral dissertation). Burnaby, BC: Simon Fraser University.

Birdi, B. \& Ford, N. (2018). Toward a new sociological model of fiction reading. Journal of the Association for Information Science and Technology, 69(11), 1291-1303. 
Blackburn, M.V. \& Clark, C.T. (2011). Becoming readers of literature with LGBT themes in and out of classrooms. In S. Wolf, K. Coats, P.A. Enciso, \& C. Jenkins (Eds.), Handbook of research on children's and young adult literature (pp. 148-163). New York: Routledge.

Brammer, J.P. (2017, October 11). LGBTQ and out on social media-but nowhere else. NBC News. Retrieved from https://www.nbcnews.com/feature/nbc-out/lgbtq-out-socialmedia-nowhere-else-n809796

Brown, B. (2017, December 12). A snapshot of American reading habits in 2017. Global English Editing. Retrieved from https://geediting.com/snapshot-american-reading-habits$\underline{2017 /}$

Cain, S. (2017, March 14). Ebook sales continue to fall as younger generations drive appetite for print. The Guardian. Retrieved from https: / / www.theguardian.com/books/2017/mar/14/ebook-sales-continue-to-fallnielsen-survey-uk-book-sales

California Department of Education. (2018). Frequently asked questions: Senate Bill 48. Retrieved from https://www.cde.ca.gov/ci/cr/cf/senatebill48faq.asp

Cart, M. \& Jenkins, C.A. (2006). The heart has its reasons: Young adult literature with gay/lesbian/queer content, 1969-2004. Lanham, MD: Scarecrow Press.

CenterLink. (2018). 2018 LGBT community center survey report: Assessing the capacity and programs of lesbian, gay, bisexual, and transgender community centers. Fort Lauderdale, FL: CenterLink. Retrieved from https: / / www.lgbtcenters.org/Assets//Documents/CC-Surveys/2018-community-center09-06.pdf

Chapman, E.L. (2013). No more controversial than a gardening display? Provision of LGBTrelated fiction to children and young people in U.K. public libraries. Library Trends, 61(3), 542-568.

Chapman, E.L. (2014, August). “I've never really thought about it": Librarians' attitudes to the provision of LGBT-related fiction to children and young people in English public libraries. Paper presented at the International Federation of Library Associations and Institutions World Library and Information Congress, Lyon, France. Retrieved from http://library.ifla.org/1017/

Chapman, E.L. (2015). Provision of LGBT-related fiction to children and young people in English public libraries: A mixed-methods study (Doctoral dissertation). Retrieved from http://etheses. whiterose.ac.uk/11802/

Cleveland, A. (2004). Library anxiety: A decade of empirical research. Library Review, 53(3), 177-185.

Commission on Reading of the National Council of Teachers of English. (2004). On reading, learning to read, and effective reading instruction: An overview of what we know and how we know it. Retrieved from http://www2.ncte.org/statement/onreading/

Cowan, T. (1988). Gay men and women who enriched the world. Boston: Alyson Publications. 
Creelman, J.A.E. (1990). Coming out: The information needs of lesbians. Collection Building 10(3/4), 37-41.

Craig, S.L. \& Mclnroy, L. (2014). You can form a part of yourself online: The influence of new media on identity development and coming out for LGBTQ youth. Journal of Gay \& Lesbian Mental Health, 18(1), 95-109.

Dashow, J. (2017, November 5). New report on youth homelessness affirms that LGBTQ youth disproportionately experience homelessness. Human Rights Campaign. Retrieved from https://www.hrc.org/blog/new-report-on-youth-homeless-affirms-that-lgbtq-youthdisproportionately-ex

DeHaan, S., Kuper, L.E., Magee, J.C., Bigelow, L., \& Mustanski, B.S. (2013). The interplay between online and offline explorations of identity, relationships, and sex: A mixedmethods study with LGBT youth. Journal of Sex Research, 50(5), 421-434.

Drag Queen Story Hour. (2018). Drag queen story hour. Retrieved from https: //www.dragqueenstoryhour.org/

Drake, A.A. \& Bielefield, A. (2017). Equitable access: Information seeking behavior, information needs, and necessary library accommodations for transgender patrons. Library \& Information Science Research, 39(3), 160-168.

Equaldex. (2018). Equaldex: the collaborative LGBT rights knowledge base. Equaldex. Retrieved from http://www.equaldex.com/

Fabian, R. (2016, May 11). 6 of the safest spaces for LGBT youth to hang online. The DailyDot. Retrieved from https://www.dailydot.com/irl/lgbt-youth-safe-spaces/

Fagan, R.W. (2013). The bullying demands of masculinity: A genderqueer escape. In S. Tarrant (Ed.), Men speak out: Views on gender, sex, and power (pp. 34-38). New York: Routledge.

Flanders, C.E., Pragg, L., Dobinson, C., \& Logie, C. (2017). Young sexual minority women's use of the internet and other digital technologies for sexual health information seeking. The Canadian Journal of Human Sexuality, 26(1), 17-25.

Foster, C. (2017, June 30). LGBTQ in sci-fi: Space is the gayest place. Foreword Reviews. Retrieved from https://www.forewordreviews.com/articles/article/lgbtq-in-sci-fispace-is-the-gayest-place/

Fox, J. \& Ralston, R. (2016). Queer identity online: Informal learning and teaching experiences of LGBTQ individuals on social media. Computers in Human Behavior, 65, 635-642.

Freely, J. (2013, June 11). Gay romance readers survey: Demographics and buying habits. Friskbiskit. [Web log]. Retrieved from http://www.friskbiskit.com/2013/06/gayromance-readers-survey-demographics-and-buying-habits.html

Garden, N. (1982). Annie on my mind. New York: Farrar, Strauss and Giroux.

Gay Lesbian Straight Education Network. (2015). Out online: The experiences of lesbian, gay, 
bisexual, and transgender youth on the Internet. New York: Gay Lesbian Straight Education Network. Retrieved from https://www.glsen.org/sites/default/files/Out\%200nline\%20FINAL.pdf

Gay Lesbian Straight Education Network. (2018). Fostering a global dialogue about LGBT youth and schools. Retrieved from https://www.glsen.org/global-dialogue-lgbt-youth-saferschools

Goldthorp, J. (2012). Where's our public library service? LGBT fact or fiction? In I. Rivers \& R. Ward (Eds.), Out of the ordinary: Representations of LGBT lives (pp. 29-43). Newcastle-on-Tyne, U.K.: Cambridge Scholars.

Hamer, J.S. (2003). Coming-out: Gay males' information seeking. School Libraries Worldwide, 9(2), 73-89.

Haas, A.P., Rodgers, P.L., \& Herman, J.L. (2014). Suicide attempts among transgender and gender non-conforming adults: Findings of the National Transgender Discrimination Survey. Retrieved from https://williamsinstitute.law.ucla.edu/wpcontent/uploads/AFSP-Williams-Suicide-Report-Final.pdf

Hegarty, P. (2011). Sexuality, normality and intelligence. What is queer theory up against? Psychology and Sexuality, 2(1), 45-57.

Hill, R.A. (2016, February 11). Almost home: How public libraries serve homeless teenagers. School Library Journal. Retrieved from https://www.slj.com/?detailStory=almosthome-how-public-libraries-serve-homeless-teenagers

Hillier, L. \& Harrison, L. (2007). Building realities less limited than their own: Young people practising same-sex attraction on the Internet. Sexualities, 10(1), 82-100.

Hillier, L., Mitchell, K.J., \& Ybarra, M.L. (2012). The Internet as a safety net: Findings from a series of online focus groups with LGB and non-LGB young people in the United States. Journal of LGBT Youth, 9(3), 225-246.

Hoskinson, M. (2001). A student's perceptions of gifted classes for GLBT youth. Advocating for Gifted Gay and Lesbian Youth, 4(1).

Hudson, J.H. (2007). Silent readers, silenced readers: LGBT student perceptions of LGBT representation in composition readers (Doctoral dissertation). Retrieved from ProQuest Dissertations and Theses. (Accession No. 304860036).

Human Rights Campaign. (n.d.). Growing up LGBT in America: HRC youth survey report key findings. Retrieved from https://assets2.hrc.org/files/assets/resources/Growing-UpLGBT-in-America_Report.pdf?_ga=2.123843466.1491450771.15387627961463265679.1538762796

Human Rights Campaign. (2018). LGBTQ youth report. Retrieved from https: //www.hrc.org/resources/2018-lgbtq-youth-report

Illinois General Assembly. (2018). Bill status of HB5596: 100 th General Assembly. Retrieved from http: / / www.ilga.gov/legislation/billstatus.asp?DocNum=5596\&GAID=14\&GA=100\&DocT 
ypelD=HB\&LegID=111602\&Session ID=91

International Federation of Library Associations and Institutions (IFLA). (2015). LGBTQ users special interest group. Retrieved from https://www.ifla.org/lgbtg

International Federation of Library Associations and Institutions (IFLA). (2016). IFLA code of ethics for librarians and other information workers (full version). Retrieved from https://www.ifla.org/publications/node/11092

International Lesbian, Gay, Bisexual, Trans and Intersex Association (ILGA). (2017). State sponsored homophobia: A world survey of sexual orientation laws: Criminalisation, protection and recognition. Retrieved from https://ilga.org/downloads/2017/ILGA_State_Sponsored_Homophobia_2017_WEB.pdf

International Reading Association. (2014). Leisure reading: A joint position statement of the International Reading Association, the Canadian Children's Book Centre, and the National Council of Teachers of English. Retrieved from http://www.literacyworldwide.org/docs/default-source/where-we-stand/leisurereading-position-statement.pdf

Joyce, S. \& Schrader, A. (1997). Hidden perceptions: Edmonton gay males and the Edmonton Public Library. Canadian Journal of Information and Library Science, 22(1), 19-37.

Kachel, D. (2018, March 16). A perfect storm impacts school librarian numbers. School Library Journal. Retrieved from https: //www.slj.com/?detailStory=perfect-storm-impactsschool-librarian-numbers

Kivel, B. \& Kleiber, D. (2000). Leisure in the identity formation of lesbian/gay youth: Personal but not social. Leisure Sciences, 22(4), 215-232.

Kosciw, J.G. \& Boesen, M.J. (2015, February 4). Finding a path: Lesbian, gay, bisexual, and transgender students' plans for life after high school [Webinar]. Retrieved from http: //www.glsen.org/webinars

Lambda Legal. (n.d.) National recommended best practices for serving LGBT homeless youth. Retrieved from https: / /www.lambdalegal.org/publications/national-recommendedbest-practices-for-lgbt-homeless-youth

Lucero, L. (2017). Safe spaces in online places: Social media and LGBTQ youth. Multicultural Education Review, 9(2), 117-128.

Marchesani, J. (2002). Science fiction and fantasy. In glbtq: an encyclopedia of gay, lesbian, bisexual, transgender, \& queer culture. Retrieved from https://web.archive.org/web/20140605215123/http://www.glbtq.com/literature/scifi fantasy.html

Marine, S.B. (2011). Stonewall's legacy: Bisexual, gay, lesbian, and transgender students in higher education. San Francisco: Jossey-Bass.

McBee, T.P. (2013, May 31). Why Tumblr is perfect for the trans community. BuzzFeed. Retrieved from https://www.buzzfeed.com/thomaspagemcbee/why-tumblr-is-perfect- 
for-the-trans-community

Moyer, J.E. (2010). “Teens today don't read books anymore”: A study of differences in interest and comprehension based on reading modalities, Part I: Introduction and methodology. The Journal of Research on Libraries and Young Adults, 1(1). Retrieved from http: // www.yalsa.ala.org/jrlya/2010/11/teens-today-dont-read-books-anymore-astudy-of-differences-in-interest-and-comprehension-based-on-reading-modalities-part1-introduction-and-methodology/

National Endowment for the Arts. (2007). To read or not to read: A question of national consequence (Research report \#47). Retrieved from https://www.arts.gov/sites/default/files/ToRead.pdf

National Endowment for the Arts. (2009). Reading on the rise: A new chapter in American literacy. Retrieved from https://www.arts.gov/sites/default/files/ReadingonRise.pdf

National Literacy Trust. (2017). Children and young people's reading in 2016: Findings from our annual literacy survey 2016. Retrieved from https: //literacytrust.org.uk/researchservices/research-reports/childrens-and-young-peoples-reading-in-2016-findings-fromour-annual-literacy-survey-2016/

Naidoo, J.C. (2014). Reaching out to LGBT youth. In K. Harrod \& C. Smallwood (Eds.), Library youth outreach: 26 ways to connect with children, young adults and their families (pp. 84-91). Jefferson, NC: McFarland.

Naidoo, J.C. (2015, August). Access to a world of rainbow family children's books via partnerships and programs: Suggestions for library outreach to LGBT family associations. Paper presented at the International Federation of Library Associations and Institutions World Library and Information Congress, Cape Town, South Africa. Retrieved from http://library.ifla.org/1289/

Norman, M. (1999). OUT on loan: A survey of the use and information needs of users of the Lesbian, Gay and Bisexual collection of Brighton and Hove Libraries. Journal of Librarianship and Information Science, 31(4), 188-196.

Oder, B. (2018, June 26). 50 queer bookstores to visit this Pride Month. BookRiot. Retrieved from https://bookriot.com/2018/06/26/queer-bookstores/

Oltmann, S.M. (2015). Variables related to school media center LGBT collections. Libri, 65(1), 25-33.

Oltmann, S.M. (2016). "They kind of rely on the library": School librarians serving LGBT students. The Journal of Research on Libraries and Young Adults, 7(1), 1-21.

Pachankis, J.E. \& Hatzenbuehler, M.L. (2013). The social development of contingent self-worth in sexual minority young men: An empirical investigation of the "Best little boy in the world" hypothesis. Basic and Applied Social Psychology, 35(2), 176-190.

Paridis, E. (2016). Searching for self and society: Sexual and gender minority youth online. In V.E. Bloomfield \& M.E. Fisher (Eds.), LGBTQ voices in education: Changing the culture of schooling (pp. 87-101). New York: Routledge. 
Peterson, V. (2018, December 16). Young adult and new adult book markets: Facts and figures to know about the young adult book market. Retrieved from https: //www.thebalancecareers.com/the-young-adult-book-market-2799954

Pruitt, J. (2016). Common queer readers band together on YouTube. The Popular Culture Studies Journal, 4(1/2), 56-82.

Rainie, L. (2018, April 9). The information needs of citizens: Where libraries fit in. Pew Research Center. Retrieved from http://www. pewinternet.org/2018/04/09/theinformation-needs-of-citizens-where-libraries-fit-in/

read. (n.d.). In Oxford Living Dictionaries. Retrieved from https://en.oxforddictionaries.com/definition/read

Riksförbundet För Sexuell Upplysning (RFSU). (2017, November 30). About Swedish sex education. Retrieved from https://www.rfsu.se/om-rfsu/om-oss/in-english/nationalwork/sexuality-education/about-swedish-sexuality-education/

Robards, B. (2017, January 23). Is there something queer about Tumblr? Scrolling Beyond Binaries. Retrieved from https://scrollingbeyondbinaries.com/2017/01/23/is-theresomething-queer-about-tumblr/

Rothbauer, P. (2004a). Finding and creating possibility: Reading in the lives of lesbian, bisexual and queer young women (Doctoral dissertation). Retrieved from ProQuest Dissertations and Theses (Accession No. NQ96911).

Rothbauer, P. (2004b). The Internet in the reading accounts of lesbian and queer young women: Failed searches and unsanctioned reading. The Canadian Journal of Information and Library Science, 28(4), 89-110.

Rothbauer, P. (2004c). “People aren't afraid anymore, but it's hard to find books": Reading practices that inform the personal and social identities of self-identified lesbian and queer young women. Canadian Journal of Information \& Library Sciences, 28(3), 53-74. Retrieved from https://works.bepress.com/paulette_rothbauer/21/

Sanlo, R.L. (2000). The LGBT campus resource center director: The new profession in student affairs. NASPA Journal, 37(3), 485-495.

Schaller, S. (2011). Information needs of LGBTQ college students. Libri: International Journal of Libraries \& Information Services, 61(2), 100-115.

slash fiction. (n.d.). In Dictionary.com. Retrieved from https://www.dictionary.com/browse/slash-fiction

Smith, T.M. (2016). Sci-fi as a queer genre. Harvard Divinity Bulletin, 44(3/4). Retrieved from https://bulletin.hds.harvard.edu/articles/summerautumn2016/sci-fi-as-queer-genre

Steinmetz, K. (2017, March 16). Beyond "he" or "she": The changing meaning of gender and sexuality. Time. Retrieved from http://time.com/4703309/gender-sexuality-changing/

Stepaniuk, C. (2018, March 16). The burning and banning of an Annie on My Mind. BookRiot. 
Retrieved from https://bookriot.com/2018/03/16/annie-on-my-mind/

Stern, M.J. (2013, September 30). Are gay people smarter than straight people? The Slate. Retrieved from https://slate.com/human-interest/2013/09/are-gay-people-smarterthan-straight-people-or-do-they-just-work-harder.html

Stewart, C. (Ed.). (2009). The Greenwood encyclopedia of LGBT issues worldwide. Santa Barbara, CA: ABC-CLIO.

Treat, A.R. (2006). Overexcitability in gifted sexually diverse populations. The Journal of Secondary Gifted Education, 17(4), 244-257.

True Colors Fund. (2018). State index on youth homelessness. Retrieved from https: //truecolorsfund.org/index/

United Nations Educational, Scientific and Cultural Organization (UNESCO). (2012a). Education sector responses to homophobic bullying. Retrieved from http: //old.outandequal.org/wpcontent/uploads/2015/05/UNESCO_Homophobic_bullying_2012_-Schools.pdf

United Nations Educational, Scientific and Cultural Organization (UNESCO). (2012b). Review of homophobic bullying in educational institutions. Retrieved from http: // unesdoc.unesco.org/images/0021/002157/215708e.pdf

Wargo, J.M. (2017). \#donttagyourhate: Reading collecting and curating as genres of participation in LGBT youth activism on Tumblr. Digital Culture \& Education, 9(1), 1431.

Wexelbaum, R. (2015a). Censorship of online LGBTIQ content in libraries. In R. Wexelbaum (Ed.), Queers online: LGBT digital practices in libraries, archives, and museums (pp. 205-214). Sacramento, CA: Litwin Books.

Wexelbaum, R. (2015b). The quest for LGBTIQ ebooks. In R. Wexelbaum (Ed.), Queers online: LGBT digital practices in libraries, archives, and museums (pp. 215-228). Sacramento, CA: Litwin Books.

Wexelbaum, R. (2017a). Do libraries save LGBT students? Library Management, 39(1/2), 31-58.

Wexelbaum, R. (2017b). Global promotion of LGBTQ resources and services through social media. In R. Montague and L. McKeever (Eds.), Queer library alliance: Global reflections and imaginings (pp. 87-122). Sacramento, CA: Library Juice Press.

Wexelbaum, R. \& Hoover, J. (2014). Gifted and LGBTIQ: A comprehensive research review. International Journal for Talent Development and Creativity, 2(1), 73-86.

Wilcove, J. (1998). Perceptions of masculinity, femininity, and androgyny among a select cohort of gifted adolescent males. Journal for the Education of the Gifted, 21(3), 288309.

Winkelstein, J.A. (2013). Safe in the stacks: Community spaces for LGBTQ homeless youth. Presented at the 2013 ALA Annual Meeting, Chicago, IL. Retrieved from 
http://www.ala.org/rt/glbtrt/tools/homeless-lgbtq-youth

Zickuhr, K. \& Rainie, L. (2014). Younger Americans' reading habits and technology use. Pew Research Center. Retrieved from http://www. pewinternet.org/2014/09/10/youngeramericans-reading-habits-and-technology-use/

Rachel Wexelbaum (rswexelbaum@stcloudstate.edu) is Collection Management Librarian and Associate Professor at St. Cloud State University in St. Cloud, Minnesota. She teaches courses on social media and LGBTIQ+ Studies to undergraduates. Currently she is pursuing her doctorate in higher education administration at St. Cloud State University, where she is studying the impact of academic libraries on LGBTQ+ undergraduates. Rachel is the editor of Queers Online: LGBT Digital Practices in Libraries, Archives, and Museums (Library Juice Press, 2015), and has written several articles and book chapters dealing with emerging library resources and services for LGBTIQ+ populations. Currently Rachel serves on the IFLA LGBTIQ+ Special Interest Group, collaborating on a survey to develop international guidelines for LGBTQ+ library resources and services. She is also the Twitter administrator for Wikimedia LGBT+, a global thematic user group devoted to promotion, creation, and improvement of LGBT+ content on Wikipedia and providing support for LGBTQ+ Wikipedians. 